Махортов Юрій Олексійович

доктор економічних наук, професор,

Київський університет культури,

Київ, Украӥна,

y_max@bk.ru;

Пономарьова Галина Олександрівна

кандидат економічних наук, дочент,

Одеський національний економічний університет,

Одеса, Україна

\title{
АНАЛІЗ СУЧАСНОЇ МІГРАЦІЙНОЇ ПОЛІТИКИ КРАЇН ЄВРОПИ
}

Актуальність даного дослідження визначається посиленнями процесів міграції, що обумовлено розвитком та поглибленням глобалізаційних та інтеграційних процесів, та виникнення процесів протилежних їм. Зазначено, що міграційні процеси суттєво впливають на напрями та темпи розвитку світової та вітчизняної економіки, демографічні процеси в більшості країн світу, підвищення чи зниження соціальних стандартів суспільства та ін. сторін нашого життя. Визначено, що на сьогоднішній час в нашій державі не існує єдиної комплексної концепції міграційної політики, яка б дозволила Україні та ії громадянам стати повноправними членами європейської спільноти із зберіганням та повноцінним захистом своїх громадянських, трудових та соціальних прав та свобод. Метою дослідження є аналіз сучасної міграційної політики країн Європи та визначення рекомендацій із посилення зв'язку вітчизняної міграційної політики із європейською. Для досягнення мети використано методи системно-структурного аналізу, логічного аналізу, фактичного аналізу та ситуаційного підходу. У процесі дослідження встановлено, що сучасна міграційна політики країн Європи формується під впливом визначених чинників: демографічна ситуація, суттєві зміни кон'юнктури сучасного ринку праці, збільшення обсягів та інтенсивності зовнішніх міграційних потоків, військові конфлікти на території України та Сирії, посилення проблеми міжнародного тероризму, перманентна фінансово-економічна криза в окремих країнах Європейського Союзу, референдум у Великій Британії, щодо рішення про вихід з СС. За результатами дослідження було сформовано рекомендації, щодо необхідності вивчення та застосування основ та принципів європейської міграційної політики за визначеними напрямами.

Ключові слова: міграція, політика, глобалізація, наслідки, історія, мігрант, переміщення, інтеграція.

Makhortov Yurii, Doctor of Economics, Professor, Kyiv University of Culture, Kyiv, Ukraine;

Ponomariova Halyna, Candidate of Economics, Associate Professor, Odesa National University of Economics, Odesa, Ukraine

\section{Analysis of migration policy of modern Europe}

The relevance of this study is determined by the strengthening of migration processes, caused by the development and deepening of globalization and integration processes, and the emergence of the opposing processes. It has been indicated that migration processes influence greatly the direction and pace of development of the global and domestic economy, demographic processes in most countries, enhancement or reduction of the social standards, and other aspects of our lives. It has been determined that nowadays our country doesn't have anyunified comprehensive concept of the migration policy that would give the country and its citizens opportunity to become high-grade members of the European Community, keep and fully protect their civil, labour and social rights and freedoms. The aim of the study is to analyse the modern migration policyof the European countries and to define recommendations onthe strengthening ofthe communication between domestic and European migration policy. Methods of the systemic, structural analysis, logical analysis, factual analysis and situational approachhave been used in order of achieving the stated aim. During the study it has been found that modern migration policy of the 
European countries is formed under the influenceof the defined factors: demographics, significant changes in conditions of the modern labour market, increase of the intensity of external migration flows, military conflicts on the territory of Ukraine and Syria, deepening of the problem of international terrorism, permanent financial crisis in some countries of the European Union, the referendum in the UK on the decision to exit the EU. According to the results of the research, recommendations on the necessityto study and applythe fundamentals and principles of the European migration policies indefinedspheres have been formed.

Key words: migration, policy, globalization, implications, history, migrant, displacement, integration

Махортов Юрий Алексеевич, доктор экономических наук, профессор, Киевский университет культуры, Киев, Украина;

Пономарева Галина Александровна, кандидат экономических наук, доцент, Одесский начиональный экономический университет, Одесса, Украина

\section{Анализ современной миграционной политики стран Европы}

Актуальность данного исследования определяется усилениями процессов миграции, что обусловлено развитием и углублением глобализационных и интеграционных процессов, а также возникновения процессов противоположных им. Отмечено, что миграционные процессы существенно влияет на направления и темпы развития мировой и отечественной экономики, демографических процессов в большинстве стран мира, повышение или снижение социальных стандартов общества и др. сторон нашей жизни. Определено, что на сегодняшний день в нашем государстве не существует единой комплексной концепции миграционной политики, которая позволила нашей стране и ее гражданам стать полноправными членами европейского сообщества с хранением и полноценной защитой своих гражданских, трудовых и социальных прав и свобод. Целью исследования является анализ современной миграционной политики стран Европы и определение рекомендаций по усилению связи отечественной миграционной политики с европейской. Для достижения цели использованы методы системно-структурного анализа, логического анализа, фактического анализа и ситуационного подхода. В процессе исследования установлено, что современная миграционная политики стран Европы формируется под влиянием определенных факторов: демографическая ситуация, существенные изменения конъюнктуры современного рынка труда, увеличение объемов и интенсивности внешних миграционных потоков, военные конфликты на территории Украины и Сирии, усиление проблемы международного терроризма, перманентная финансово-экономический кризис в отдельных странах Европейского Союза, референдум в Великобритании, по решению о выходе из ЕС. По результатам исследования были сформированы рекомендации относительно необходимости изучения и применения основ и принципов европейской миграционной политики по определенным направлениям.

Ключевые слова: миграция, политика, глобализация, последствия, история, мигрант, перемещение, интеграция.

Вступ. Глобальні процеси сучасності, прискорення вироблення, отримання та засвоєння інформації в сучасному економічному просторі викликає, як наслідок, суттєве зростання темпів та масштабів міграційних процесів у світі, зокрема, і в країнах Європи.

Нині час дуже актуальним стає аналіз та глибинне дослідження міграційних процесів, як явища, яке суттєво впливає на напрями та темпи розвитку світової та вітчизняної економіки, демографічних процесів у більшості країн світу, підвищення чи зниження соціальних стандартів суспільства та ін. сторін нашого життя.

Існуючі підходи, які пропонують розглядати та аналізувати міграцію та міграційні процеси, як такі, що впливають відокремлено на різні сфери державної політики та суспільного життя нині виявляються не ефективними. Із розвитком, прискоренням та поглибленням процесів 
інтеграції України до європейської спільноти необхідно досліджувати міграційні процеси та міграційну політику держави комплексно, системно, реалізовувати такий концептуальний підхід, який дозволить критично розглядати вплив міграції на економіку, соціальну сферу, суспільне та культурне життя, найкращим чином дозволить впроваджувати та імплементувати світовий та європейський досвід становлення, розвитку та вдосконалення питань міграційної політики.

Аналіз останніх досліджень і публікацій. Світова наукова спільнота вже виробила моделі процесів міжнародної міграції населення. Такі моделі відображено у працях Дж. Борхаса, А. Роя, К. Макконела, Я. Мінсера, Маноло І. Абеллі та ін.

Питання міжнародної міграції та державної міграційної політики розглядаються у працях таких вітчизняних науковців: Ю. Г. Пуригіна, С. П. Калініна, Т. О. Гнатюк, Ю. П. Гуменюк, В. Капітан, І. П. Майданік, О. А. Малиновська, М. Ю. Приз, І. В. Ховрах. У роботах вищезгаданих авторів розглядаються теоретико-методологічні засади розвитку міграційних процесів в Україні, визначаються основні види міграції та їх особливості, наслідки міграційних процесів, приділяється увага проблемам формування ефективної міграційної політики держави.

Виділення невирішених раніше частин загальної проблеми. В умовах поглиблення глобалізацій них процесів у міжнародних економічних відносинах міграція набула нового масштабного характеру, змісту та якісних характеристик. Однак, необхідно зазначити, що на сьогоднішній час в нашій державі не існує єдиної комплексної концепції міграційної політики, яка 6 дозволила нашій країні та їі громадянам стати повноправними членами європейської спільноти із зберіганням та повноцінним захистом своїх громадянських, трудових та соціальних прав i свобод. Існує певна недосконалість статистичного та інформаційного забезпечення досліджень 3 питань міграційної політики провідних країн світу, та таких, які є донорами, невідповідність світовим та європейським показникам, що ускладнює об'єктивний аналіз міграційних процесів.

Постановка завдання. Метою даного дослідження $\epsilon$ аналіз сучасної політики країн Європи, що надасть змогу визначити основні напрями та виклики такої політики для України на сучасному етапі розвитку відносин нашої держави з європейською спільнотою та військової агресії сході країни.

Основним завданням дослідження є узагальнення європейського міграційного досвіду 3 огляду на його імплементацію у практику міграційної політики України з метою її вдосконалення.

Основна частина. Посилення та прискорення процесів глобалізації у світовому господарстві обумовило і появу глобальних проблем людства, однією з яких і є глобальна демографічна проблема, сутність якої полягає у стрімкому збільшенні чисельності населення та нерівномірному демографічному його розвитку, що, насамперед, підсилює масштаби та швидкість світових міграційних процесів, які нині характеризуються переміщенням мігрантів між усіма континентами. I тому вирішення глобальної демографічної проблеми можливо за умов поєднання зусиль усіх країн світу, спираючись на досвід провідних держав, які мають певний багатолітній досвід формування ефективної міграційної політики.

Саме така політика, спрямована на використання інтелектуального та фізичного потенціалу кваліфікованих спеціалістів дала змогу таким країнам як США, Канада, Німеччина, Франція та ін. державам Західної Європи значно посилити національний потенціал. Однак, треба зазначити, що лише невелика кількість країн стає місцем постійного проживання для міжнародних мігрантів.

У 10 країнах з найбільшою кількістю міжнародних мігрантів зосереджено близько 52 \% від їх загальної чисельності, з європейських країн це - Німеччина, Франція, Велика Британія, Іспанія і Україна [4; 6].

Сучасна міграційна політика країн Європи формується та здійснюється під впливом цілого комплексу факторів, з яких можна виділити наступні:

- демографічна ситуація (старіння нації) у більшості європейських країн. За даними статистики якщо у $2012 \mathrm{p}$. населення працездатного віку країн $\mathrm{CC}$ (15-64 роки) становило 335,6 млн. осіб, то на 2060 р., за прогнозом, нараховуватиметься лише 
290,6 млн. працездатних європейців. Демографічне навантаження особами старшого віку (тобто співвідношення чисельності непрацездатних осіб старшого віку до чисельності працездатного населення) становило 26,8 \%, а в 2060 р. зросте до 52,6 \%. Таке суттєве навантаження призводить, а в майбутньому посилиться до проблем у функціонуванні пенсійної системи, забезпеченні потреб національних економік робочою силою, в тому числі, висококваліфікованою [2];

- суттєві зміни кон'юнктури сучасного ринку праці;

- збільшення обсягів та інтенсивності зовнішніх міграційних потоків. Більшість дослідників міграційних процесів наголошують на тому, що міграція до країн Європи розглядається з позицій прибуття до них мігрантів з країн, що розвиваються, країн 3 перехідною (трансформаційною) економікою, які в більшості $\epsilon$ пострадянськими. При аналізі сучасної європейської міграційної політики треба неодмінно враховувати, що за масштабами переміщень внутрішні міграції в країнах Європи в чотири рази більші, ніж зовнішні [3];

- військові конфлікти на території України та Сирії, посилення проблеми міжнародного тероризму. Дуже важливим напрямом формування та здійснення міграційної політики з огляду на цей фактор $є$ безперервний та посилений контроль за дотриманням законності міграційних процесів, запобіганням та рішучою боротьбою з нелегальною міграцією;

- перманентна фінансова-економічна криза в окремих країнах Європейського Союзу;

- референдум у Великій Британії щодо рішення про вихід з СС.

Для нашої держави одним 3 головних напрямів сучасної міграційної європейської політики, без сумніву, є отримання безвізового режиму. Однак ЄС наголошує на необхідності всебічного запобігання використанню вже існуючих легальних каналів для нелегальної міграції 3 метою запобігання викривлення європейського ринку праці 3 причин нелегальної міграції, скоротити та не допустити збільшення кількості клопотань про надання притулку у країнах Європи з причин, які не мають об’єктивних підстав.

Останні розширення Європейського Союзу, які відбувалися 32004 до 2013 рр., значно збільшили не тільки кількісний, але й якісний склад цього інтеграційного об'єднання, суттєво ускладнили процес регулювання міграційних процесів та функціонування європейської міграційної політики взагалі. Це призвело до формування спільного зовнішньоекономічного напряму міграційної політики СС та інших країн Європи, який включає в себе не тільки співробітництво з країнами-донорами, але й з країнами-членами $Є С$, та європейськими країнами, які не є його членами [7].

Важливим аспектом сучасної європейської міграційної політики $є$ питання інтеграції та реінтеграції мігрантів в європейську спільноту. Бо саме глибина та ефективність заходів 3 інтеграції ставить у залежність остаточний результат імміграції, яка повинна бути спрямована на підвищення потенціалу кожної національної економіки країн, що приймають мігрантів. Однак, на практиці, ми бачимо і негативні наслідки, виникнення кризових та кримінальних ситуацій, які порушують однорідність суспільства, яке $є$ приймаючим. I саме дії уряду та громадське суспільство повинно забезпечити та приймати активну участь у процесах і заходах з інтеграції та реінтеграції.

Такі процеси ускладнюються суттєвим різноманіттям мігрантів, як за країнами походження, так і за ступенем освіти і кваліфікації, релігійними переконаннями та соціальнокультурними ознаками, правовим статусом, мотивами міграції, термінами перебування у країнах Європи та головною метою міграції [5].

Висновок i перспективи подалыших досліджень. За результатами дослідження міграційної політики країн Свропи можна зробити висновок, про те, що вплив та взаємозв'язок міграційної політики європейських країн на вітчизняну міграційну політику досить неоднозначний та складається з декількох напрямів.

В якості першого напряму можна виділити політику Європейського Союзу, яка стосується віз, боротьби з нелегальною міграцією, запрошення до імміграції кваліфікованих спеціалістів і вмотивованих студентів, захисту прав легальних мігрантів. Саме такий напрям міграційної 
політики став одним із найвпливовіших факторів зростання міграційних потоків громадян України до європейських країн. Результатом впливу цього чиннику стало збільшення частин трудових мігрантів, які працюють у європейських країнах, зросла кількість студентської молоді, що навчається в освітніх закладах, спеціалісти відповідних професій та кваліфікацій також обирають країнами перебування та заробітку країни Свропи.

Другим напрямом, без сумніву, є прагнення українського суспільства до побудови демократичного суспільства 3 верховенством права та дотримання законності у всіх сферах суспільного життя. I саме це орієнтує міграційні потоки до країн Європи та вибудовує міграційну політику України на засадах, які застосовуються у країнах ЄС та забезпечують права людини.

Саме інтеграційний вектор співпраці України з СС та ін. країнами Європи у сфері міграції забезпечує певні потоки інформаційної, науково-технічної та фінансової допомоги 3 метою забезпечення повноцінного державного регулювання міграційних потоків з боку вітчизняного уряду.

Однак, треба зазначити, що відсутність послідовної орієнтації на інтеграцію саме до країн Європи до 2014 р., чітко визначених національних пріоритетів перешкоджало всебічному застосуванню наявних, розроблених та апробованих інструментів міжнародного співробітництва, зокрема, Східного партнерства.

Отримання безвізового режиму для українців у країнах $Є С$ вплине на посилення транскордонної мобільності саме в напрямку країн Європи, і це означає необхідність вивчення та застосування основ і принципів європейської міграційної політики за наступними напрямами [1]:

- посилення соціального забезпечення та захисту прав українських мігрантів у країнах Європи;

- посилення партнерства з міжнародної мобільності;

- розробка спільних проектів, що забезпечують та сприяють поверненню українських мігрантів, які отримують освіту на батьківщину;

- запровадити програми освітньої міграції в Україну за європейськими стандартами із забезпеченням відповідної якості освіти;

- розробка та впровадження відповідних програм реінтеграції мігрантів, які повертаються до України;

- розробка та впровадження державних і громадських програм і проектів 3 інтеграції мігрантів в українське суспільство;

- значно посилити активність наукових досліджень у сфері міграції міжнародної та внутрішньої, побудованих на європейських принципах і засадах [5].

\section{Список використаних джерел:}

1. Малиновська О. А. Міграційна політика Європейського союзу: виклики та уроки для України / О. А. Малиновська. - Київ: НІСД, 2014. - 48 с.

2. 4th Annual Report on Immigration and Asylum (COM/2013 422 final) [Electronic resource]. Mode of access: http://ec.europa.eu/dgs/homeaffairs/elibrary/documents/policies/immigration/general/docs/4th_annual_report_on_immigration_and_as ylum_en.pdf. - Last access: 23.02.2017. - Title from the screen.

3. Eurostat [Electronic resource]. - Mode of access: http://appsso.eurostat.ec.europa.eu/nui/submitViewTableAction.do . - Last access: 23.02.2017. - Title from the screen.

4. Geddes A. The Politics of Migration and Immigration in Europe / A. Geddes. - London: Thousand Oaks ; New Delhi: SAGE Publications, 2003. - P. 138.

5. Patrutiu-Baltes L. The Brain Drain Phenomenon within the European Union. [online] / L. Patrutiu-Baltes. - 2014. - Available at: http://one-europe.info/brain-drain-eu. - Last access: 26.02.2017. - Title from the screen. 
6. World Bank World Development Indikators Database [Electronic resource]. - Washington: World Bank, 2014. - Mode of access: http://data.worldbank.org/data-catalog/world-developmentindicators. - Last access: 26.02.2017. - Title from the screen.

7. World Migration in Figures, 2013. [pdf] OECD-UNDESA. Available at: http://www.oecd.org/els/mig/World-Migration-in-Figures.pdf. - Last access: 26.02.2017. - Title from the screen.

\section{References:}

1. Malynovska, O.A. (2014). European Union Migration Policy: Challenges and Lessons for Ukraine. Kyiv: NISD.

2. 4th Annual Report on Immigration and Asylum (COM/2013 422 final). [online] Available at: http://ec.europa.eu/dgs/home-

affairs/elibrary/documents/policies/immigration/general/docs/4th_annual_report_on_immigration_and_as ylum en.pdf. [Accessed 23 February 2017]. Title from the screen.

3. The EU. Eurostat. [online]. Available at: http://appsso.eurostat.ec.europa.eu/nui/submitViewTableAction.do. [Accessed 23 February 2017]. Title from the screen.

4. Geddes, A. (2003). The Politics of Migration and Immigration in Europe. London; Thousand Oaks; New Delhi: SAGEPublications.

5. Patrutiu-Baltes, L. (2014). The Brain Drain Phenomenon within the European Union. [online] Available at: http://one-europe.info/brain-drain-eu. [Accessed 26 February 2017]. Title from the screen.

6. The World Bank. (2014). World Bank World Development Indikators Database. Washington. [Online] Available at: http://data.worldbank.org/data-catalog/world-development-indicators. [Accessed 26 February 2017]. Title from the screen.

7. The UN. OECD-UNDESA. (2013). World Migration in Figures. [online] Available at: http://www.oecd.org/els/mig/World-Migration-in-Figures.pdf. [Accessed 26 February 2017]. Title from the screen.

(С) Махортов Ю. О., Пономарьова Г. О., 2018 